\title{
Antimicrobial potential of various fractions of Thuja orientalis
}

\author{
Joginder Singh Duhan ${ }^{1^{*}}$, Pooja Saharan ${ }^{1}$, Surekha ${ }^{2}$ and Ashok Kumar ${ }^{1}$ \\ ${ }^{1}$ Department of Biotechnology, CDLU Sirsa, 125055, Haryana, India. \\ ${ }^{2}$ Department of Botany, Government National P.G. College, Sirsa, 125055, Haryana, India.
}

Accepted 3 June, 2013

\begin{abstract}
The present study was conducted to evaluate the antimicrobial activity of various extracts (viz. methanol, acetone and ethyl acetate) of Thuja orientalis and its preliminary phytochemical screening. In vitro antimicrobial activity was tested by agar well diffusion assay against human pathogenic microbes which are Gram positive (viz. S. aureus and B. subtilis), Gram negative bacteria (viz. $P$. aeruginosa, $A$. faecalis and $K$. pneumoniae) and fungi ( $A$. flavus and $A$. niger). Methanol and acetone extract of leaf exhibited maximum activity against $B$. subtilis with zones of inhibition of $20.33 \mathrm{~mm}$ and $17.83 \mathrm{~mm}$, respectively. All the extracts of stem were found to be most effective against $P$. aeruginosa. $S$. aureus was found to be sensitive to leaf extracts prepared in methanol, acetone and ethyl acetate with 13.66, 14.03 and $15.00 \mathrm{~mm}$ zone of inhibition, respectively. $A$. flavus and $A$. niger, both were found to be sensitive towards the methanol extract of leaf with inhibition zones of 15.50 and $16.00 \mathrm{~mm}$, respectively compared to fungicides (viz. ketoconazole and fluconozole). Methanol extract of leaf and ethyl acetate extract of stem exhibit marked antimicrobial activity against $B$. subtilis and $P$. aeruginosa, which was comparable to standard antibiotics (that is, penicillin, ampicillin, tetracycline and streptomycin). It was also observed that leaf extracts were more effective as compared to stem extracts of the plant. Thus, Thuja orientalis could be considered as potential source of natural antimicrobials used for the treatment of bacterial and fungal infections.
\end{abstract}

Key words: Plant extracts, antibacterial activity, minimal inhibitory concentration, phytochemical screening.

\section{INTRODUCTION}

Plant material based traditional medicines are readily available in rural areas at relatively cheaper than modern medicine (Mann et al., 2008). This plant-based, traditional medicine system continues to play an essential role in health care, with about $80 \%$ of the world's inhabitants relying mainly on traditional medicines for their primary health care (Owolabi et al., 2007). According to World Health Organization, medicinal plants would be the best source to obtain a variety of drugs. Therefore, such plants should be investigated to better understand their properties, safety and efficacy (Nascimento et al., 2000). In general, these plants are used in folk medicine in the treatment of skin diseases, venereal diseases, respiratory problems and nervous disorders. The medicinal value of plants lies in some chemical substances that produce a definite physiological action on the human body. The most important bioactive compounds of plants are alkaloids, flavanoids, tannins and phenolic compounds (Edeoga et al., 2005).

Plant products still remain the principal source of pharmaceutical agents used in traditional medicine (Ibrahim, 1997; Ogundipe et al., 1998). Recently, interest in a large number of traditional natural products has increased (Thongson et al., 2004). 
Microorganisms have developed resistance to many antibiotics and this has created immense clinical problem in the treatment of infectious diseases (Davis, 1994). Also antibiotics and other synthetic drugs show adverse effects on host like ulcers, hypersensitivity etc. besides their high cost. So, a retrospection of the healing power of plants and a return to natural remedies is an absolute need of our time. The effects of plant extracts on bacteria have been studied by a very large number of researchers in different parts of the world (Reddy et al., 2001; Ateb and Urul, 2003).

Due to the above reasons, herbal extracts of Thuja orientalis was tested against selected human pathogenic strains that is $B$. subtilis (causal organism of dysentery), $S$. aureus (responsible for nausea, vomiting, diarrhea and dehydration), Pseudomonas aeruginosa (infects the pulmonary tract, urinary tract, burns, wounds and causes blood infections), Klebsiella pneumoniae (causal organism of pneumonia), Alcaligens faecalis (nosocomial septicaemia in immunocompromised patients) and two fungal strains viz. Aspergillus niger (allergic bronchopulmonary aspergillosis) and Aspergillus flavus (released aflatoxin B1 which is a potent liver carcinogen).

Thuja occidentalis has been used to treat bronchial catarrh, enuresis, cystitis, psoriasis, uterine carcinomas, amenorrhea and rheumatism (Chang et al., 2000). Thuja occidentalis and Thuja orientalis are two different species belonging to the same family Cupresseaceae. Thuja occidentalis are slow-growing trees native to North America (also known as American cedar) and grows in dense wet forests in South Eastern Canada and the North Western United States. It grows up to a height of about $60 \mathrm{ft}(18.2 \mathrm{~m})$, with trunks between 12 and 24 in $(31$ and $61 \mathrm{~cm})$ in diameter. On the other hand, Thuja orientalis was an endemic tree of North Western China (also known as Chinese cedar) but now naturalised as an introduced species in Asia: eastward to Korea and Japan; southward to Northern India; and westward to Northern Iran. It is a short tree growing to a height of only $12-20 \mathrm{ft}$ (4-6 m), and is sometimes used to form hedges as it tolerates pruning. Chinese cedar, however, is not as hardy as its North American counterparts (http://www.altmd.com/Articles/Thuja--Encyclopedia-of-

Alternative-Medicine). The essential oil from seed coats of $T$. orientalis was screened for antimicrobial activity by Jain and Garg et al. (1997) while its antioxidant activity was studied by Duhan et al. (2013). Based on the above fact, in the present study, various extracts of stem and leaf of Thuja orientalis were screened for their antimicrobial activity.

\section{MATERIALS AND METHODS}

\section{Collection of Plant material}

The plant material $(5.0 \mathrm{~kg}$.) was collected from the locality of Sirsa (India) located between 29.14-30.0 North latitude and 74.29-75.18 East longitudes. Stem and leaves were thoroughly washed, shade- dried for $72 \mathrm{~h}$ and powdered material was stored for further use.

\section{Culture media and chemical}

Nutrient broth and Czapek yeast extract were purchased from $\mathrm{Hi}-$ media (Mumbai, India) while the organic solvents (methanol, acetone, ethyl acetate, chloroform and hexane) were obtained from Qualigens ((Mumbai, India).

\section{Test microrganisms}

Five bacterial strains that is Bacillus subtilis MTCC 441, Staphylococcus aureus MTCC 87, Pseudomonas aeruginosa MTCC 424, Klebsiella pneumoniae MTCC 109, Alcaligens faecalis MTCC 126 and two fungal strains viz., Aspergillus niger MTCC 404 and Aspergillus flavus MTCC 873 were used as test microorganisms. Microbial cultures were preserved as stab slant cultures at $4^{\circ} \mathrm{C}$.

\section{Preparation of plant extracts}

The different extracts of stem and leaf of Thuja orientalis were prepared by decreasing order of solvent polarity (Figure 1). In this method, the extraction was started with a highly polar solvent that is water, which was followed by methanol, acetone and ethyl acetate.

The filtrate of each solvent was air dried at room temperature for solvent elimination and the extracts of each solvent were kept in refrigerator at $4^{\circ} \mathrm{C}$ until use. Extracts obtained were weighed and percentage of yield $(\mathrm{w} / \mathrm{w})$ was calculated.

\section{Antibacterial activity testing assay}

Agar well diffusion assay described by Perez et al. (1990) was used for testing antibacterial and antifungal activity. One hundred microliter suspension of $24 \mathrm{~h}$ old culture of test organism was inoculated on the agar plates and spread on to the surface of the agar with a sterilized glass spreader. After five minutes of inoculation of test microorganism, wells $(2.5 \mathrm{~mm}$ diameter) were prepared with the help of sterilized steel cork borer. Wells of each plate were loaded with $60 \mu \mathrm{l}$ of crude plant extracts $(1 \mathrm{mg} / \mathrm{ml})$ along with the control (respective extraction solvent). Same method was repeated for antibiotics viz., tetracyclin, streptomycin, ampicillin, penicillin and fungicides viz., ketoconazole and fluconozole (used as positive control) under similar conditions. The plates were then aerobically incubated for $24 \mathrm{~h}$ at $30 \pm 2^{\circ} \mathrm{C}$ for $\mathrm{S}$. aureus and at $37 \pm 2^{\circ} \mathrm{C}$ for other bacterial strains.

\section{Antifungal assay}

Agar well diffusion assay described by Perez et al. (1990) was also used for testing antifungal activity. One hundred microliter spore suspension of activated cultures of fungal strains were inoculated on the Czapek-yeast agar (CYA) plates and spread on to the surface of the CYA with a sterilized glass spreader. After five minutes of inoculation of test microorganism, wells $(2.5 \mathrm{~mm}$ diameter) were prepared with the help of sterilized steel cork borer. Wells of each plate were loaded with $60 \mu \mathrm{l}$ of crude plant extracts along with the control (respective extraction solvent). Same method was repeated for fungicides viz., ketoconazole and fluconozole (used as positive control) under similar conditions. The plates were then aerobically incubated at $28 \pm 2^{\circ} \mathrm{C}$ for $72 \mathrm{~h}$ for both fungal test organisms. 
$100 \mathrm{~g}$ leaf/stem powder

Extraction with water (thrice) $24 \mathrm{~h}$ at room temperature

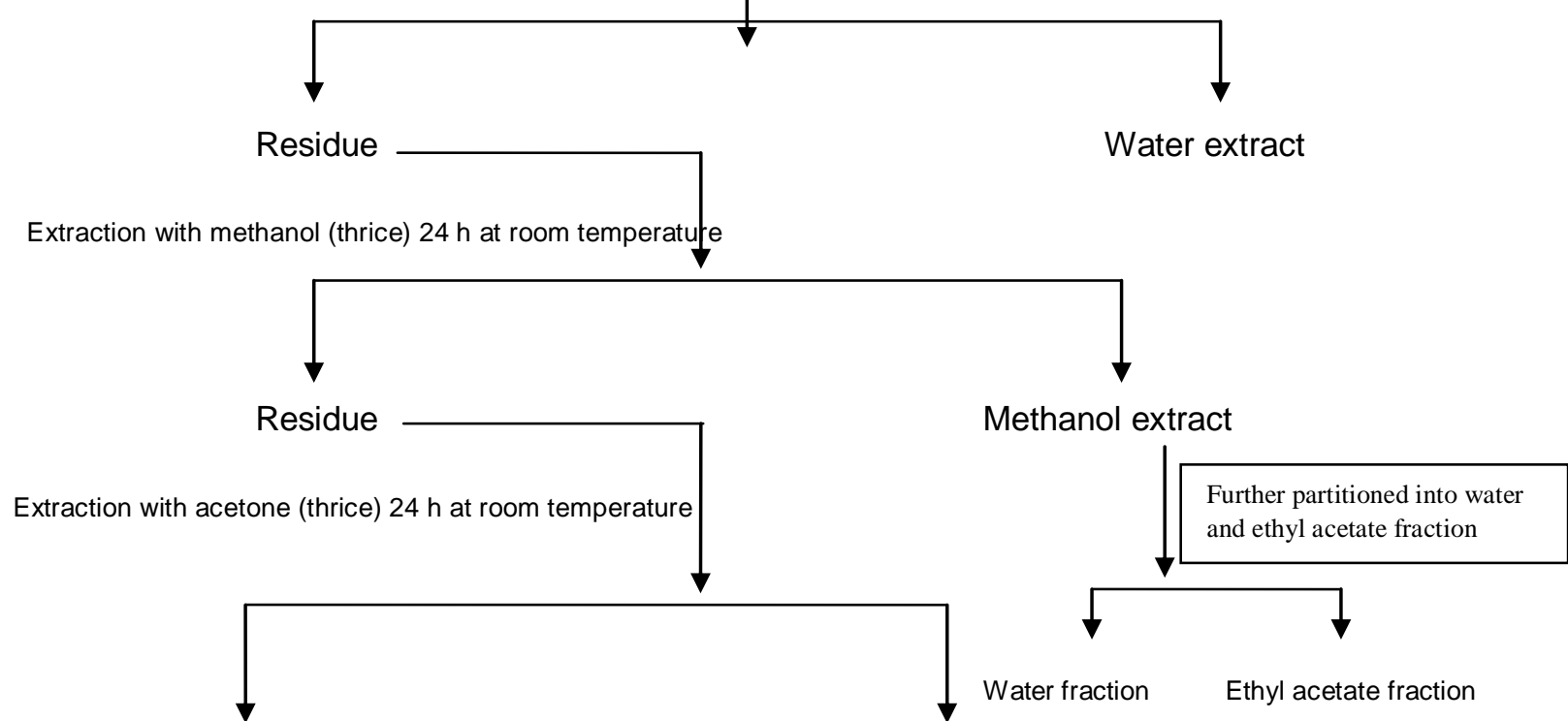

Residue

Acetone extract

Extraction with ethyl acetate (thrice) $24 \mathrm{~h}$ at room temperature

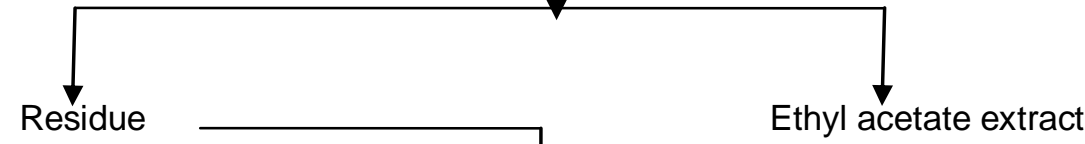

Extraction with chloroform (thrice) $24 \mathrm{~h}$ at room temperature

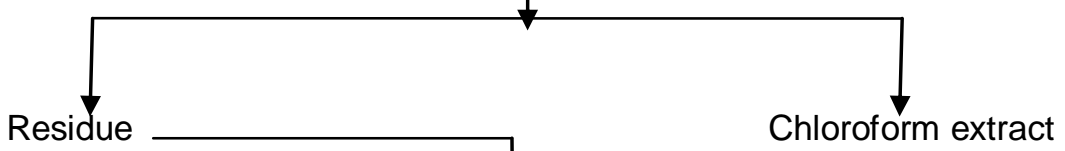

Extraction with hexane (thrice) $24 \mathrm{~h}$ at room temperature

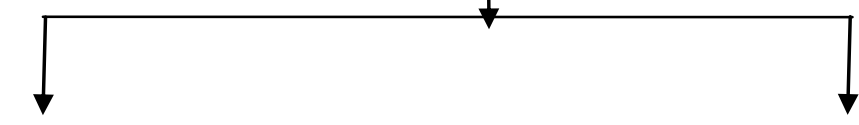

Residue

Hexane extract

Figure 1 Extraction of leaf and stem powder of Thuja orientalis by decreasing order of solvent polarity.

\section{Minimum inhibition concentration (MIC) of the extracts}

The MIC was defined as the lowest concentration that completely inhibited the growth of microorganisms for $24 \mathrm{~h}$ (Thongson et al., 2004). MIC of the extracts was also carried out using agar well diffusion technique (Perez et al., 1990). The bacterial strain was cultured in nutrient broth and then incubated at $37^{\circ} \mathrm{C}$ for $18-24 \mathrm{~h}$. In this method $60 \mu \mathrm{l}$ of $24 \mathrm{~h}$ old culture of test organism was inoculated on the agar plates and spread on to the surface of the agar with the help of a sterilized glass spreader. After five minutes of inoculation of test microorganism, wells (2.5 mm diameter) were prepared with the help of sterilized steel cork borer. Each well of agar plate was loaded with $60 \mu \mathrm{l}$ of different concentrations (serial dilution ranging from $250-800 \mu \mathrm{g} / \mathrm{ml}$ and $1.0-3.5 \mathrm{mg} / \mathrm{ml}$ of extracts were prepared) of tested plant extract. The plates were then aerobically incubated at $30 \pm 2^{\circ} \mathrm{C}$ for $\mathrm{S}$. aureus, at $37 \pm 2^{\circ} \mathrm{C}$ for $24 \mathrm{~h}$ for other bacterial strains and at $28 \pm 2^{\circ} \mathrm{C}$ for $72 \mathrm{~h}$ for fungal test organisms. The lowest concentration of the extracts showing a clear 
Table 1. Extractive value of stem and leaf extracts of $T$. orientalis.

\begin{tabular}{llc}
\hline \multirow{2}{*}{ Extract } & \multicolumn{2}{c}{ Extractive values (\%) } \\
\cline { 2 - 3 } & Leaf & Stem \\
\hline Methanol & 3.60 & 2.20 \\
Acetone & 1.63 & 0.91 \\
Ethyl acetate & 0.78 & 0.55 \\
\hline
\end{tabular}

zone of inhibition was considered as the MIC.

\section{Preliminary phytochemical analysis of the extracts}

To assess the chemical composition of the various extracts qualitatively, a preliminary phytochemical analysis was conducted according to the standard methods of Sofowora (1993) and Trease and Evans (2002). Using these methods, the presence of several phytochemicals like sterols, tannins, proteins, sugars, alkaloids, flavonoids, saponins, anthraquinones, terpenoids, and cardiac glycosides was evaluated.

\section{Test for sterols (Salkowaski reaction)}

A few milligrams of the plant extract were dissolved in $2 \mathrm{ml}$ chloroform and then $2 \mathrm{ml}$ of conc. H2SO 4 was added from the sides of the test tube. The test tube was shaken for a few minutes. Red colour development in the chloroform layer indicated the presence of sterols.

\section{Test for tannins (Ferric chloride reagent test)}

The test sample of each extract was taken separately in water, warmed and filtered. To a small volume of this filtrate, a few drops of $5 \% \mathrm{w} / \mathrm{v}$ solution of ferric chloride prepared in $90 \%$ alcohol were added. Appearance of a dark green or deep blue colour indicated the presence of tannins.

\section{Test for proteins (Xanthoproteic test)}

The extract (few $\mathrm{mg}$ ) was dissolved in $2 \mathrm{ml}$ water and then $0.5 \mathrm{ml}$ of conc. HNO3 was added into it. Yellow colour indicated the presence of proteins.

\section{Test for sugars (Fehling's test for free reducing sugar)}

About $0.5 \mathrm{~g}$ of each extract was dissolved in distilled water and filtered. The filtrate was heated with $5 \mathrm{ml}$ of equal volumes of Fehling's solution A and B. Formation of a red precipitate of cuprous oxide was an indication of the presence of reducing sugars.

\section{Test for flavonoids (Ferric chloride test)}

About $0.5 \mathrm{~g}$ of each extract was boiled with $5.0 \mathrm{ml}$ of distilled water and then filtered. To $2.0 \mathrm{ml}$ of this filtrate, a few drops of $10 \%$ ferric chloride solution were added. A green-blue or violet colouration indicated the presence of a phenolic hydroxyl group.

\section{Test for saponins}

One gram of each extract was boiled with $5 \mathrm{ml}$ of distilled water and filtered. To the filtrate, about $3 \mathrm{ml}$ of distilled water was further added and shaken vigorously for about 5 min. Frothing which persisted on warming was taken as an evidence for the presence of saponins.

\section{Test for anthraquinones}

An aliquot of $0.5 \mathrm{~g}$ of the extract was boiled with $10 \mathrm{ml}$ of sulphuric acid (H2SO4) and filtered while hot. The filtrate was shaken with 5 $\mathrm{ml}$ of chloroform. The chloroform layer was pipetted into another test tube and $1 \mathrm{ml}$ of dilute ammonia was added. The resulting solution was observed for colour changes.

\section{Test for terpenoids (Salkowski test)}

To $0.5 \mathrm{~g}$ of each extract, $2 \mathrm{ml}$ of chloroform was added, followed by a further addition of $3 \mathrm{ml}$ of concentrated $\mathrm{H} 2 \mathrm{SO} 4$ to form a layer. A reddish brown colouration of the interface indicated the presence of terpenoids.

\section{Test for cardiac glycosides (Keller-Killiani test)}

To $0.5 \mathrm{~g}$ of the extract diluted to $5 \mathrm{ml}$ in water, $2 \mathrm{ml}$ of glacial acetic acid containing one drop of ferric chloride solution was added. This was under layed with $1 \mathrm{ml}$ of concentrated sulphuric acid. A brown ring at the interface indicated the presence of a deoxysugar characteristic of cardenolides. A violet ring may appear below the brown ring, while in the acetic acid layer a greenish ring may form just above the brown ring and gradually spread throughout this layer.

\section{Statistical analysis}

Antimicrobial activity of various extracts of stem and leaf of $T$. orientalis was statistically analysed along with standard antibiotics by applying t-test.

\section{RESULTS AND DISCUSSION}

Table 1 shows extractive values of different extracts prepared, it was found maximum that is $3.60 \%$ in methanol extract of leaf while minimum that is $0.55 \%$ in case of ethyl acetate extract of stem. Data in Figure 2 indicates the antibiotic susceptibility of the bacterial and fungal isolates used in this research. Methanol extract of leaf exhibited maximum activity against $B$. subtilis with a zone of inhibition of $20.33 \mathrm{~mm}$ (Figure 3) followed by $P$. aeruginosa $(16.66 \mathrm{~mm}), A$. flavus $(16.00 \mathrm{~mm})$ and $A$. niger $(15.50 \mathrm{~mm})$. B. subtilis was also highly sensitive to acetone extract (with an inhibition zone of $17.83 \mathrm{~mm}$ ) of leaf. Acetone extract of leaf also showed marked antibacterial activity against $P$. aeruginosa $(16.00 \mathrm{~mm}), S$. aureus $(14.83 \mathrm{~mm}$ ) and $A$. facealis (14.06 mm, Figure 4). Likewise $S$. aureus was found to be sensitive against ethyl acetate extract of leaf (with an inhibition zone of 15 $\mathrm{mm}$ ). In case of stem extracts, ethyl acetate extract exhibit maximum inhibition zone that is $17.50 \mathrm{~mm}$ against $P$. aeruginosa. All the extracts of stem that is methanol, acetone, ethyl acetate were found to be effective against $P$. aeruginosa (Figure 2). It was also observed that leaf extracts were more effective compared to the stem extracts of the plant. 


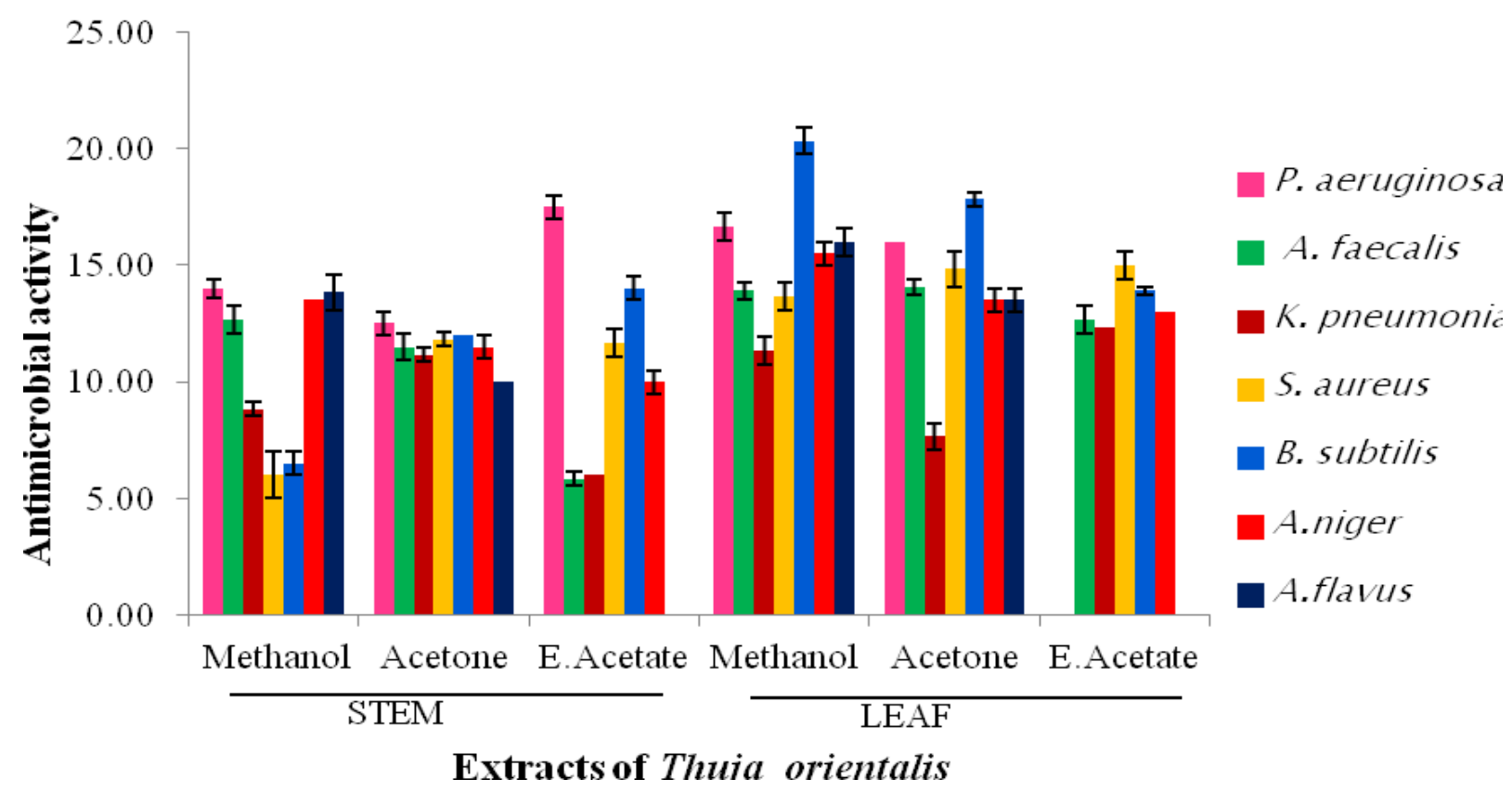

Figure 2. in vitro antimicrobial activities of various extracts of stem and leaf of Thuja orientalis by agar well diffusion assay.

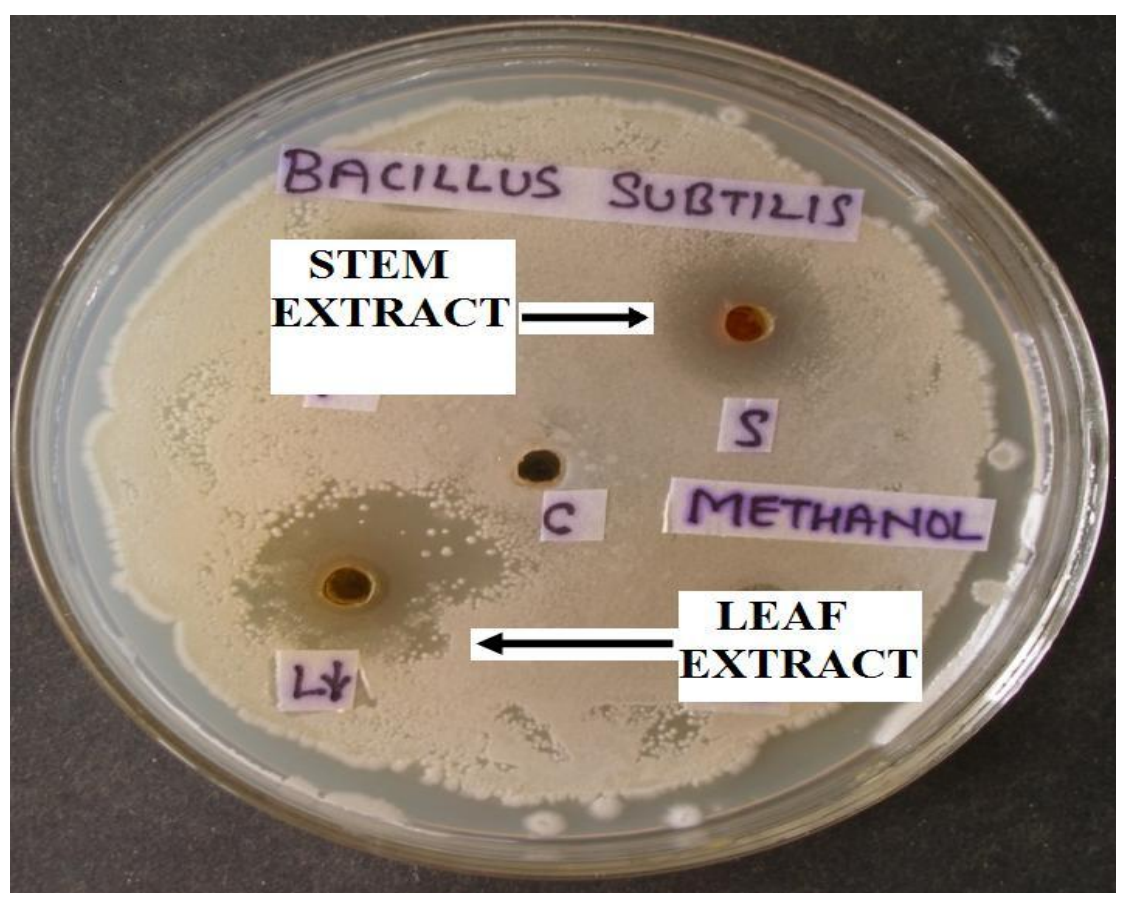

Figure 3. Inhibitory effect of methanol extracts of stem and leaf of Thuja orientalis on B. subtilis.

The antibacterial activity of all these extracts was compared with standard antibiotics and fungicides. It was observed that acetone extract of leaf possess equal antibacterial activity as exhibited by ampicillin against $P$. aeruginosa, $A$. faecalis and $K$. pneumoniae (Table 2). Antibacterial effect of methanol extract of leaf against $P$. aeruginosa, $A$. faecalis and $K$. pneumonie was also acceptable with respect to the standard antibiotics like penicillin and ampicillin. Likewise methanolic extract of leaf exhibited more fungicidal activity against $A$. favus and $A$. niger as compared to fluconozole and ketoconozole, the standard fungicide used as positive and $A$. niger 


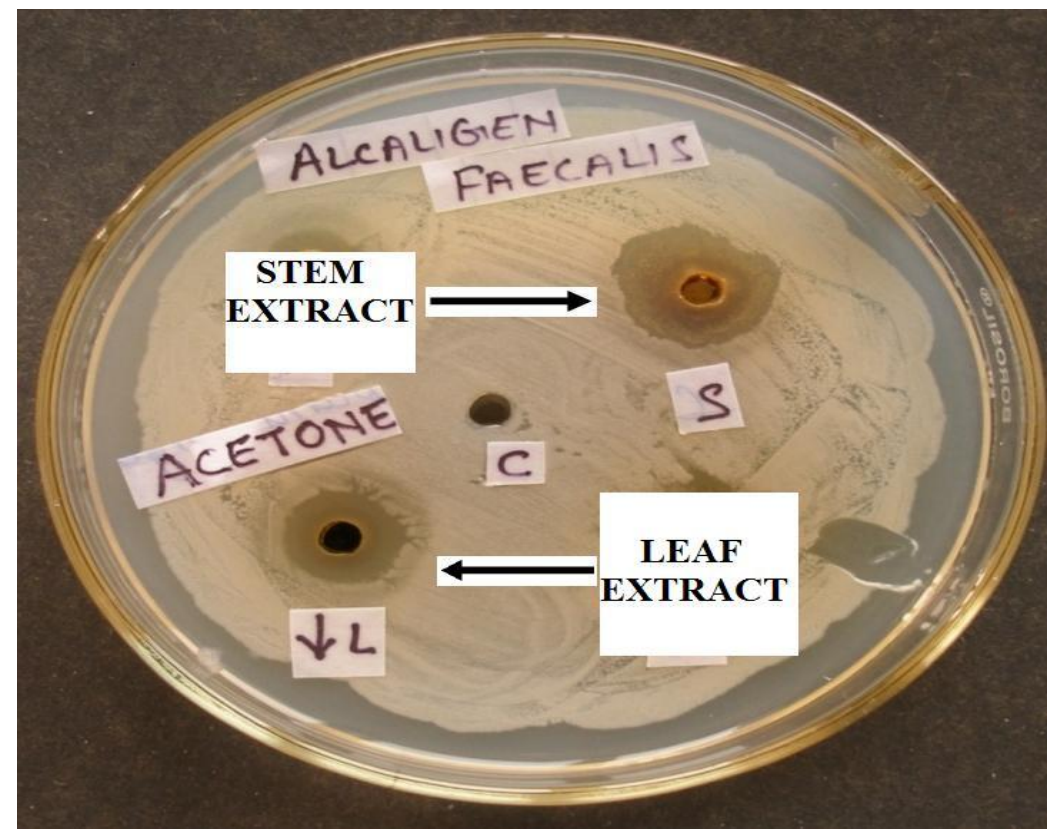

Figure 4. Inhibitory effect of acetone extracts of stem and leaf of Thuja orientalis on $A$. faecalis.

Table 2. In vitro antimicrobial activity of different standard antibiotics $(500 \mathrm{mg} / \mathrm{ml})$ by agar well diffusion assay.

\begin{tabular}{lccccccc}
\hline \multirow{2}{*}{ Antibiotic } & \multicolumn{7}{c}{ Zone of inhibition $(\mathbf{m m})$} \\
\cline { 2 - 8 } & $\boldsymbol{P . \text { aeruginosa }}$ & A. faecalis & K. pneumoniae & B. subtilis & S. aureus & A. flavus & A. niger \\
\hline Penicillin & $14.00 \pm 1.00$ & $10.66 \pm 0.58$ & $7.00 \pm 1.00$ & $20.16 \pm 0.76$ & $13.00 \pm 0.00$ & - & - \\
Ampicillin & $16.00 \pm 0.00$ & $10.00 \pm 0.54$ & $9.33 \pm 0.58$ & $26.83 \pm 1.04$ & $17.06 \pm 0.11$ & - & - \\
Tetracyclin & $20.66 \pm 0.58$ & $17.50 \pm 0.00$ & $17.00 \pm 0.50$ & $22.00 \pm 1.00$ & $21.00 \pm 0.00$ & - & - \\
Streptomycin & $23.00 \pm 1.00$ & $14.50 \pm 1.00$ & $11.83 \pm 0.76$ & $19.00 \pm 0.00$ & $13.83 \pm 0.28$ & - & - \\
Fluconozole & - & - & - & - & - & $14.00+00$ & $15.00+0.2$ \\
Ketoconozole & - & - & - & - & - & $14.00+0.2$ & $13.00+0.2$ \\
\hline
\end{tabular}

All values are mean of three replicates.

\pm = standard deviation; - =No activity

as compared to fluconozole and ketoconozole, the standard fungicide used as positive control in this study. The results reveal that acetone and methanol extracts of leaf are potent antimicrobials against the above mentioned three pathogenic bacteria and two fungi studied and were acceptable with respect to the standard antibiotics and fungicides (Figure 2). So, we can replace the synthetic antibiotics with plant extract based antimicrobial medicines. The potential activity of plant extracts against tested microorganisms was also determined by measuring minimum inhibitory concentration (MIC). The lower the MIC value of extract the better is its action against microbes. The acetone extracts of leaf and methanolic extract of stem inhibited the growth of $\mathrm{B}$. subtilis and $A$. faecalis respectively at lower concentration that is 800 $\mu \mathrm{g} / \mathrm{ml}$ (Table 3).

Antimicrobial activity of various extracts of stem and leaf of Thuja oreintalis along with standard antibiotics was also analysed statistically by applying t-test. Results show that the antimicrobial activity of methanol and ethyl acetate extracts of stem was found significant at $5 \%$ and $10 \%$ level which were comparable with the standard antibiotics penicillin and ampicillin. Acetone extract was found to be non significant. On the other hand, in case of leaf extracts, antimicrobial activity of methanol and acetone extract was significant even at $1 \%$ level which was comparable with the standard antibiotic streptomycin and even better than penicillin and ampicillin (Table 4) while in ethyl acetate it was non significant.

The phytochemical screening of the crude methanol, acetone and ethyl acetate extracts was carried out in order to analyze the presence of secondary metabolites (such as flavonoids, alkaloids, saponins, tannins) by utilizing standard methods of analysis of Sofowora (1993) and 
Table 3. The MIC values of different plant extracts of Thuja orientalis by agar well diffusion assay.

\begin{tabular}{|c|c|c|c|c|c|c|c|c|}
\hline Extract & $\begin{array}{l}\text { Plant } \\
\text { Part }\end{array}$ & $\begin{array}{c}\text { Pseudomonas } \\
\text { aeruginosa }\end{array}$ & $\begin{array}{l}\text { Alcaligenes } \\
\text { faecalis }\end{array}$ & $\begin{array}{c}\begin{array}{c}\text { Klebsiella } \\
\text { pneumoniae }\end{array} \\
\end{array}$ & $\begin{array}{c}\text { Staphylococcus } \\
\text { aureus }\end{array}$ & $\begin{array}{l}\text { Bacillus } \\
\text { subtilis }\end{array}$ & $\begin{array}{c}\text { Aspergillus } \\
\text { flavus }\end{array}$ & $\begin{array}{c}\text { Aspergillus } \\
\text { niger }\end{array}$ \\
\hline \multirow{3}{*}{ Methanol } & Control & - & - & - & - & - & - & - \\
\hline & Stem & * & $800 \mu \mathrm{g} / \mathrm{ml}$ & $1.5 \mathrm{mg} / \mathrm{ml}$ & * & $1.0 \mathrm{mg} / \mathrm{ml}$ & $1.0 \mathrm{mg} / \mathrm{ml}$ & * \\
\hline & Leaf & $1.0 \mathrm{mg} / \mathrm{ml}$ & * & $1.0 \mathrm{mg} / \mathrm{ml}$ & $1.0 \mathrm{mg} / \mathrm{ml}$ & * & - & * \\
\hline \multirow{3}{*}{ Acetone } & Control & - & - & - & - & - & - & - \\
\hline & Stem & $1.0 \mathrm{mg} / \mathrm{ml}$ & * & $2.0 \mathrm{mg} / \mathrm{ml}$ & * & $1.5 \mathrm{mg} / \mathrm{ml}$ & $2.5 \mathrm{mg} / \mathrm{ml}$ & $2.5 \mathrm{mg} / \mathrm{ml}$ \\
\hline & Leaf & $1.5 \mathrm{mg} / \mathrm{ml}$ & * & $1.5 \mathrm{mg} / \mathrm{ml}$ & * & $800 \mu \mathrm{g} / \mathrm{ml}$ & $1.5 \mathrm{mg} / \mathrm{ml}$ & $1.5 \mathrm{mg} / \mathrm{ml}$ \\
\hline \multirow{3}{*}{$\begin{array}{l}\text { Ethyl } \\
\text { Acetate }\end{array}$} & Control & - & - & - & - & & - & - \\
\hline & Stem & $2.5 \mathrm{mg} / \mathrm{ml}$ & * & $2.5 \mathrm{mg} / \mathrm{ml}$ & $2.5 \mathrm{mg} / \mathrm{ml}$ & $2.0 \mathrm{mg} / \mathrm{ml}$ & $1.5 \mathrm{mg} / \mathrm{ml}$ & $2.5 \mathrm{mg} / \mathrm{ml}$ \\
\hline & Leaf & $1.0 \mathrm{mg} / \mathrm{ml}$ & * & * & $1.5 \mathrm{mg} / \mathrm{ml}$ & * & * & * \\
\hline
\end{tabular}

${ }^{*}=$ not tested; - = no activity.

Table 4. T-test statistics of antimicrobial activity of various extracts of Thuja orientalis along with the standard antibiotics.

\begin{tabular}{ccccccccccc}
\hline & \multicolumn{3}{c}{ Stem } & \multicolumn{1}{c}{ Leaf } & \multicolumn{3}{c}{ Standard Antibiotics } \\
\hline & Methanol & Acetone & $\begin{array}{c}\text { Ethyl } \\
\text { acetate }\end{array}$ & Methanol & Acetone & $\begin{array}{c}\text { Ethyl } \\
\text { acetate }\end{array}$ & Penicillin & Ampicillin & Tetracyclin & Streptomycin \\
\hline t-value & $5.959^{* *}$ & $51.976^{\#}$ & $4.837^{* *}$ & $9.849^{*}$ & $8.159^{*}$ & $3.940^{\#}$ & $5.988^{* *}$ & $5.026^{* *}$ & $19.628^{\#}$ & $8.144^{*}$ \\
\hline
\end{tabular}

* Significant at $1 \%$ level; ** Significant at $5 \%$ level; *** Significant at $10 \%$ level; \# Non-significant.

Table 5. Phytochemical constituents of stem and leaf of Thuja orientalis.

\begin{tabular}{|c|c|c|c|c|c|c|c|}
\hline \multirow{2}{*}{ Phytochemical } & \multirow{2}{*}{ Test } & \multicolumn{3}{|c|}{ Stem } & \multicolumn{3}{|c|}{ Leaf } \\
\hline & & ME & $\mathbf{A E}$ & Et Act & ME & $\mathbf{A E}$ & Et Act \\
\hline Flavanoids & Ferric chloride & + & + & - & + & + & + \\
\hline Alkaloids & Wagner's test & + & + & + & + & - & + \\
\hline Free reducing sugar & Fehling's test & + & + & + & + & + & + \\
\hline Saponins & Frothing test & + & + & - & + & + & + \\
\hline Tanins & Ferric chloride reagent test & + & - & - & + & + & + \\
\hline Sterols & Salkowski reaction & + & + & + & + & + & + \\
\hline Proteins & Xanthoproteic test & + & + & - & + & + & + \\
\hline Terpenoids & Salkowski test & + & + & + & + & + & - \\
\hline Anthraquinones & Borntrager's test & + & + & - & + & + & + \\
\hline Cardiac glycosides & Keller-Killiani test & + & - & - & + & + & + \\
\hline
\end{tabular}

Key: + = present; - = absent; $\mathrm{ME}=$ methanol extract; $\mathrm{AE}=$ acetone extract; $\mathrm{Et}$ Act $=$ ethyl acetate extract.

and Trease and Evans (2002). Table 5 shows the results of the preliminary phytochemical analysis. The presence of flavanoids, alkaloids, sterols and tannins etc. in methanol extract of leaf is responsible for its maximum antimicrobial activity against $B$. subtilis (Table 5, Figure 2). The study of Tim Cushnie et al. (2005) justifies that the presence of flavanoids in plant extracts are responsible for its antibacterial as well as antifungal activity. Free sterols of Tridax procumbens totally inhibited spore germination of the fungi (Sharma and Kumar, 2009). Banso and Adeyemo (2007) detected that tannins, alkaloids and glycosides are responsible for antibacterial activity of leaf extract of Dichrostachys cinerea. Hence, phytochemicals present in leaf and stem of $T$. orientalis plant are responsible for antimicrobial properties of their extracts. Preliminary phytochemical analysis in the present study also ascertains the presence of some potential group of bioactive substances (Ghosh et al., 2008). 


\section{Conclusion}

The present investigation showed that stem and leaf extracts of Thuja orientalis are quite effective against various pathogenic microorganisms. Therefore, it can be concluded that it may be used as natural antimicrobial agent to control the infection caused by the pathogens which otherwise becomes resistant to synthetic antibiotics.

\section{REFRENCES}

Ateb DA, Erdo Urul OT (2003). Antimicrobial activities of various medicinal and commercial plant extracts. Turk. J. Biol. 27: 157-162.

Banso A, Adeyemo SO (2007). Evaluation of antibacterial properties of tannins isolated from Dichrostachys cinerea. Afr. J. Biotechnol. 6 (15): 1785-1787.

Chang LC, Song LL, Park EJ, Luyengi L, Lee KJ, Norman R (2000).Bioactive constituents of Thuja occidentalis. J. Natural Product. 63: 1235-1238.

Davis J (1994). Inactivation of antibiotics and the dissemination of resistance genes.Science.264: 375-382.

Edeoga HO, Okwu DE, Mbaebie BO (2005). Phytochemical constituents of some Nigerian medicinal plants. Afr. J. Biotechnol. 4: 685688.

Ghosh A, Das BK, Chatterjee SK, Chandra G (2008). Antibacterial potentiality and phytochemical analysis of mature leaves of Polyalthia Iongifolia (Magnoliales: Annonaceae). The South Pacific J Natural Sci. 26: 68-72.

http://www.altmd.com/Articles/Thuja--Encyclopedia-of-AlternativeMedicine

Ibrahim MB (1997). Anti-microbial effects of extract of leaf, stem, root and bark of Anogeissus leiocarpus on Staphylococcus aureaus, Streptococcus pyogenes, Escherichia coli and Proteus vulgaris. J. Pharma. Devpt. 2: 20-30.

Jain RK, Garg SC (1997). Antimicrobial activity of the essential oil of Thuja orientalis L. Ancient Sci. Life. 16(3):186-189.

Mann A, Banso A, Clifford LC (2008). An antifungal property of crude plant extracts from Anogeissus leiocarpus and Terminalia avicennioides. Tanzania J. Health Res. 10 (1): 34-38.

Nascimento GGF, Lacatelli J, Freitas PC, Silva GL (2000).Antibacterial activity of plant extracts and phytochemicals on antibiotic-resistant bacteria. Braz. J. Microbiol. 31(4): 886-891.

Ogundipe O, Akinbiyi O, Moody JO (1998) Antibacterial activities of essential ornamental plants. Nigeria J. Natural Products \& Medicine.2: 46-47.
Owolabi J, Omogbai EKI, Obasuyi O (2007). Antifungal and antibacterial activities of the ethanolic and aqueous extract of Kigelia africana (Bignoniaceae) stem bark. Afr. J. Biotechnol. 6 (14): 882-85.

Perez C, Paul M and Bazerque P (1990). An Antibiotic assay by the agar well diffusion method. Acta. Biol. Med. Exp. 15: 113-115.

Reddy PS, Jamil K, Madhusudhan P (2001). Antibacterial activity of isolates from Piper longum and Taxus baccata. Pharma. Biol. 39: 236-238.

Duhan JS, Saharan P, Gahlawat SK and Surekha (2013).Antioxidant potential of various extracts of stem of Thuja orientalis: in vitro study. Int. J. App. Bio. \& Pharma. Tech. 3(4): 264-271.

Sharma B, Kumar P (2009). In vitro antifungal potency of some plant extracts against Fusarium oxysporum. Int. J. Green Pharm. 3(1): 6365.

Sofowora A (1993). Screening Plants for Bioactive Agents. In: Medicinal Plants and Traditional Medicinal in Africa.2nd Ed. Spectrum Books Ltd, Sunshine House, Ibadan, Nigeria, pp 134-156.

Tim Cushnie TP, Lamb AJ (2005). Antimicrobial activity of flavonoids. Int. J. Antimicro. Agents. 26: 343-356

Thongson C, Davidson PM, Mahakarrchanakul W and Weiss J (2004). Antimicrobial activity of ultrasound-assisted solvent-extracted spices. Lett. Appl. Microbiol. 39: 401-406.

Trease GE, Evans WC (2002). Textbook of Pharmacognosy. 15th ed. Saunders Publishers, London., 42-44, 221-229, 246-249, 304-306, 331-332, 391-393. 